\title{
ELN Gene
}

National Cancer Institute

\section{Source}

National Cancer Institute. ELN Gene. NCI Thesaurus. Code C75333.

This gene is involved in the structure of the extracellular matrix. 